\title{
Vad är 'andligt' i hypotesen om den andlige revolutionen?
}

\author{
ERIKA WILLANDER
}

\begin{abstract}
ENGLISH ABSTRACT: The Spiritual Revolution hypothesis suggests that "traditional forms of religion, particularly Christianity, are giving way to holistic spirituality, sometimes still called 'New Age"' (Heelas \& Woodhead 2005). This article addresses the conceptualisation of 'religion' and 'spirituality' and the measurement used to study the phenomena. Religion and spirituality are studied by analyses of data from the Swedish locality study called the Enköping Study, inspired by the study supporting the spiritual revolution claim. In contrast to the findings that support this claim, religion and spirituality seem to be related in the Swedish case. However, the analysis also indicates that other supposed key differences (e.g. between sources of transcendence) are not measured by the used survey questions.
\end{abstract}

DANSK RESUME: Hypotesen om den åndelige revolution (Heelas \& Woodhead 2005) forudsætter, at religionens rolle formindskes til fordel for åndelighed. Religion defineres $i$ denne sammenhæng som kristendom, der står $i$ kontrast til åndelighed, som antages at have rødder $i$ new age og alternativ medicin. Denne artikel undersøger, hvordan religion og åndelighed forstås og operationaliseres i forbindelse med hypotesen om den åndelige revolution samt datamateriale indsamlet $i$ det såkaldte Enköpingsprojekt. Resultatet viser, at kristendom ikke er udelukket fra brug af alternativ medicin, og at religion og åndelighed er relateret. Som spørgsmålene er udformet, er det dog ikke muligt at udsige noget om andre formodede forskelle (fx mellem kilder til guddommelighed).

KEYWORDS: The Spiritual Revolution Claim, Sweden, Spirituality, Religion, Survey

Sveriges förhållande till religion beskrivs fortfarande i termer av fortgående sekularisering (Gustafsson \& Pettersson 2000). Sekulariseringsbeskrivningarna har bland andra kompletterats av Heelas \& Woodhead (2005) vilka introducerat en hypotes om en andlig revolution presenterad i The Spiritual Revolution. Why Religion is Giving Way to 
Religion. Den kontroversiella och uppmärksammade hypotesen utgår från att religion förvisso minskar i betydelse samtidigt som andra former av andlighet växer sig starkare. Argumentet bygger på att religion och andlighet definieras som skilda fenomen med olika karaktäristika. Religion förknippas i dessa sammanhang med organisationer såsom kyrkor, vikten av att följa traditioner och religiöst givna regler, kollektivism samt en gudsbild vilken placerar det heliga utanför människan. I kontrast till detta sammankopplas andlighet med nätverk utan övergripande organisation, vikten för individen att 'följa sin egen röst', subjektivism samt en bild av det heliga inom människan. Källan till det heliga, det vill säga om det gudomliga finns utanför eller inom människan, betraktas som den springande punkten vilken särskiljer religion från andlighet. När Heelas \& Woodhead (2005) preciserar begreppet religion likställs det med kristna samfund medan andligheten innebär olika former av alternativmedicin. ${ }^{2}$

Syftet med denna artikel är att diskutera hur religion och andlighet förstås och operationaliseras i argumentet om den andliga revolutionen. Mot bakgrund av detta syfte tar denna artikel upp följande frågeställningar:

1. Hur kan alternativmedicinens andlighet beskrivas?

2. Vilka samband finns mellan religion, andlighet och inställning till källan för det gudomliga?

Artikeln inleds med en begreppsdiskussion om religion och andlighet i relation till begreppsförståelsen för hypotesen om den andliga revolutionen. Härefter följer en presentation av forskningsläget angående hur revolutionen operationaliserats och studerats. Först efter detta diskuteras det material som använts för analysen i denna artikel vilket samlats in inom ramen för det så kallade Enköpingsprojektet (se även Ahlstrand \& Gunner 2008). Artikeln avslutas med kommentarer om möjliga tolkningar av resultatet och tankar om resultatets betydelse för kommande undersökningar.

\section{Den andliga revolutionen definitioner av religion och andlighet}

I boken The Spiritual Revolution. Why Religion is Giving Way to Spirituality (2005) formulerar Heelas \& Woodhead hypotesen om den andliga revolutionen på följande sätt:

- Life-as forms of the sacred, which emphasize a transcendent source of significance and authority to which individuals must conform at the expense of the cultivation of their unique subjective-lives, are most likely to be in decline;

2 När begreppen religion och andlighet används i denna artikel åsyftas Heelas \& Woodheads (2005) begreppsförståelse ifall inget annat tydligt framgår av sammanhanget. 
- Subjective-life forms of the sacred, which emphasize inner sources of significance and authority and the cultivation or sacralisation of unique subjective-lives, are most likely to be growing.

(Heelas \& Woodhead 2005, 6)

Genom denna hypotes påbörjar Heelas \& Woodhead en definition av religion och andlighet. Definitionen utgår från att källan till det gudomliga är en central indikator för att skilja den religion som är på tillbakagång från den andlighet som är på tillväxt. Formuleringen ger utrymme för flera tolkningsmöjligheter. En möjlig tolkning är att 'religion' innefattar flera av världsreligionerna såsom kristendom, judendom och islam varpå andlighet är världsreligionerna buddhism och hinduism (Barker 2004). Definieras religion och andlighet på detta sätt blir förväntningarna på omdaning i samhället stora om hypotesen om den andliga revolutionen har empiriskt stöd.

Heelas \& Woodhead (2005) preciserar begreppsbildningen för den andliga revolutionen genom att hänvisa religion till kristna församlingar och andlighet till den 'holistiska miljön' representerad av alternativmedicinska terapier och metoder. Denna definition befästs också genom operationaliseringen i Kendalprojektet vilket resulterade i The Spiritual Revolution (Heelas \& Woodhead 2005). ${ }^{3}$ Det här betyder att 'religion/ kristendom' och 'andlighet/alternativmedicin' betraktas som två entiteter (två religioner). Jämförelser är enligt möjliga då de två entiteterna antas innefatta liknande dimensioner (såsom lära och praxis). Vidare ger begreppsbestämingen 'religion' och 'andlighet' olika ursprung vilket gör att religion kan betraktas som det traditionella alternativet och andlighet som det nya alternativet vilket importerats alltsedan 1960-talet.

Sättet att definiera religion och andlighet ger upphov till en rad frågeställningar. För det första, står kristendom och alternativmedicin i konkurrensförhållande till varandra? Revolutionshypotesen utgår från att en minskning av religiositet i viss mån förklaras av en ökning av alternativmedicin (Heelas \& Woodhead 2005). Lena Löwendahl visar i sin avhandling om New Age (definierat som utövare av alternativmedicin) att dessa söker vetenskapliga bevis för sina metoder samtidigt som de förhåller sig kritiska till den bild de har av kyrkor (Löwendahl 2002). Trots detta har etablerade alternativmedicinska metoder sedan länge haft en plats i Svenska kyrkan (Rosengren \& Nilsson 2007). Härutöver understryker revolutionens definitioner att kristendom och alternativmedicin ska skilja sig åt utifrån deras syn på källan till det gudomliga (religion har en yttre källa medan alternativmedicinen har en inre). Boel Hössjer Sundman (2006) menar i sin avhandling att de föreställningar om gudsnärvaro som framträder i Svenska kyrkans handbok ger utrymme för att flera föreställningar kan samexistera. Tanken om att Gud även finns inom människan behöver på så sätt inte vara motsägelsefull i relation till att Gud också finns bortom denna värld i svenskluthersk

3 Detaljerad lista över de verksamheter vilka ingick i Kendalprojektet återfinns i Appendix 3 i The Spiritual Revolution (Heelas \& Woodhead 2005, 156-58). 
teologi (Hössjer Sundman 2006). Utöver detta kan också ifrågasättas om alternativmedicin är så pass andligt att där finns en gemensam föreställning om källan till det gudomliga.

\section{Forskningsläge}

Undersökningen vilken ligger till grund för hypotesen om den andliga revolutionen genomfördes i det så kallade Kendal-projektet. Projektet genomsyrades av en antropologisk metodologi vilken innebar att de involverade forskarna observerade vilka religiösa respektive andliga verksamheter som fanns i staden Kendal. Därefter delades enkäter ut till deltagare och ledare i dessa verksamheter. På detta sätt ville forskarna undersöka attityder och trosövertygelser hos de 'innersta kretsarna' (översättning av engelskans 'heartlands") av religion och andlighet. För att enbart få med de 'innersta kretsarna' av andlighet delades endast enkäter ut till deltagare i aktiviteter som verksamhetens ledare själv ansåg var andlig. Präster och pastorer antogs på förhand betrakta gudstjänster som religiösa varpå ingen motsvarande selektion genomfördes bland kyrkorna. Härutöver delades endast enkäter ut till deltagare i andliga verksamheter vilka innebar ett personligt möte mellan människor (alltså inte produkter för hemmabruk). När detta urval fastställts bestämdes en vecka då enkäter delades ut och alla deltagare (oavsett om de svarade på enkäten eller inte) i religion respektive andlighet räknades. Ett stort arbete lades ned på att varje deltagare endast skulle räknas en gång så att antalet var möjligt att relatera deltagarna till befolkningen i staden Kendal med omgivning.

Resultatet visade att 7,9 procent av Kendals befolkning deltog i religiösa sammanhang och 1,6 procent i andliga. Vidare fann Heelas \& Woodhead att det var olika människor som deltog i det religiösa respektive det andliga (Woodhead och Heelas 2005, 31). Genom en analys av utbudet av andliga verksamheter över tid bland annat i telefonkataloger från 1960-talet och framåt antogs vidare den procent av befolkningen som deltog i andlig verksamhet öka till det dubbla på 30-40 år. Kyrkligheten antogs vidare minska under denna tid vilket utmynnar i andligheten år 2030 antas omfatta lika många människor som religiositeten och därefter bli större än religiositeten (Heelas \& Woodhead 2005, 149). Resultatet bygger främst på antalsräkningen inom Kendal. Vad gäller de enkäter som delades ut till de religiösa och de andliga i Kendal ställdes till största del olika frågor. Heelas \& Woodhead menar dock att ett bevis för anlighetens innersta kärna ligger i linje med deras teori är att 82,4 procent instämmer med det finns en makt eller kraft vilken genomsyrar allt liv. ${ }^{4}$ Voas \& Bruce (2006) menar att detta inte är tillräckligt för att betrakta alternativmedicinen som andlig och understryker att det vanligaste motivet för att besöka verksamheten (23,2 procent) var hälsa och träning (min

4 Heelas \& Woodhead 2005. Se även data från http://www.lancs.ac.uk/fss/projects/ieppp/kendal/index. htm. (set 8.6.2009) (red.) 
översättning från engelskan 'health and fitness"). Näst vanligast var andlig utveckling (19,4 procent) vilket också medförde att endast var femte deltagare motiverade sitt besök med andlighet (Voas \& Bruce 2007). Motsvarande frågor ställs inte till de religiösa. De kristna församlingsmedlemmarna antogs sluta upp kring den andliga revolutionens definition av religion bland annat genom att 57,2 procent anser att andlighet är att 'följa Guds vilja' (Heelas \& Woodhead 2005, 25).

Formen för Kendal-projektet har, med vissa justeringar, används för att studera religion och andlighet ibland annat i Danmark (Ahlin 2007) och i Sverige (Willander 2008). För den svenska undersökningen ändrades urvalsförfarandet från att genom observationer ta reda på vilka verksamheter som fanns i undersökningsområdet till att använda de företagsregister som Statistiska centralbyrån förfogar över. Anledningen till detta var att man via observationsmetoden främst får kännedom om den verksamhet som utannonseras medan uppgifterna i företagsregistret är systematiskt insamlade. Registren kompletterades sedan med icke-kommersiell verksamhet såsom studiecirklar. Alla företagare, oavsett deras inställning till andlighet, ingick i urvalet.

Utifrån uttrycket 'A Revolution in Personal Faith' argumenterar Heelas \& Woodhead $(2005,73)$ för att resultat från enkätundersökningar om människors tro också talar för hypotesen om den andliga revolutionen. Argumentet finner sin grund i att en ökande andel människor i Storbritannien väljer att beskriva sin tro på det gudomliga i termer av en 'opersonlig makt eller kraft' alternativt som 'Gud finns snarare inom varje människa än utanför' (min översättning från Heelas \& Woodhead 2005, 73-4). Heelas inleder boken Spiritualities of Life. New Age Romanticism and Consumptive Capitalism (2008) med orden:

Surprisingly, a recent survey finds that 37 per cent of the British sample agrees with the statement, "I believe that God is something within each person, rather than something out there". Whatever might be made of this - and some will express disbelief - the finding serves to direct attention to inner forms of the sacred (Heelas 2008, 1).

Den enkätfråga som Heelas refererar till och som oftast används för att mäta syn på Gud är följande:

1. Vilket av nedanstående påståenden stämmer bäst in med din uppfattning?

a) Jag tror på en Gud som man kan ha en personlig relation till

b) Jag tror på en opersonlig högre makt eller kraft

c) Jag tror att Gud snarare är något inom människan än något utanför

d) Jag tror inte på någon Gud, övernaturlig makt eller kraft

e) Jag vet inte vad jag ska tro

För att tolka svarsalternativen "Jag tror på en opersonlig högre makt eller kraft" och "Jag tror att Gud snarare är något inom människan än något utanför" som indikatorer för revolutionens andlighet behöver de förstås som uttryck för att det gudomligas källa 
finns inom människan. Nuvarande frågeformuleringen är dock problematisk eftersom den hyser svarsalternativ som överlappar varandra. Alternativet 'Gud inom människan' ger explicit Gud en rumslig placering. Det gör inte alternativet "en Gud som man kan ha en personlig relation till" eller 'en opersonlig makt eller kraft'. Är svarspersonerna familjära med kristen tradition tolkas troligtvis alternativet "en Gud som man kan ha en personlig relation till" i termer av att detta rör sig om en Gud utanför människan. Min kritiska fråga till detta är om denna kunskap fortfarande är allmänt utbredd bland den svenska befolkningen. Alternativet 'en opersonlig makt eller kraft' skulle kunna tolkas som att det gudomliga genomsyrar allt vilket även borde inkludera människors inre.

Tolkningen att svarsalternativen "Jag tror på en opersonlig högre makt eller kraft" och "Jag tror att Gud snarare är något inom människan än något utanför" är indikatorer på andlighet stämmer endast delvis överens med det de ansågs mäta vid introducerandet av alternativen. Alternativet "Jag tror på en opersonlig högre makt eller kraft" kom till som en kontrast till begreppet 'personlig Gud'. Särskiljandet mellan en 'personlig Gud' och 'en makt/kraft' är i enkätsammanhang troligtvis en importerad fråga vilken i USA fungerade väl för att mäta ortodox kristen i relation till annorlunda föreställningar (jämför Gustafsson 1981, 13, för samtida användning se Newport 2008).

Fungerar då svarsalternativen 'personlig Gud' och 'en makt/kraft' på samma sätt i Sverige som i ursprungslandet USA? Sverige har en lång tradition av enkätundersökningar om religion och redan i den första förekommer en reservation om att frågan om en personlig Gud kan vara mångtydig. Fogelklou-Norlinds (1934) skriver:

Det är mycket viktigt att framhålla, hur samma ord kan ha högst olika betydelse för skilda personer. Så t.ex. fattas ordet personlig framför Gud av somliga antropomorfiskt begränsade, av andra såsom ett uttryck för högsta möjliga grad av livsrikedom och andlig realitet (Fougelklou-Norlind 1934, 12).

Enligt Fougelklou-Norlind finns ibland en spänning mellan livsåskådningsbegrepp (eller teologiska begrepp) och inställning till religion. I vissa fall accepteras begreppen utan förklaring (såsom begreppet 'personlig Gud"). Andra tar avstånd från begreppet samtidigt som de tecknar en bild av sin inställning vilken kan vara liktydig med begreppet (Fougelklou-Norlind 1934, 22-3).

Frågekonstruktionen med svarsalternativen 'personlig Gud' och 'en makt/kraft' användes i den världsomspännande enkätundersökningen World Value Survey (WVS) mellan åren 1982-1999. ${ }^{5}$ Resultatet för Sveriges del visar att vanligaste hållningen är en tro på en opersonlig makt eller kraft. År 1999 uppger 52,4 procent av svenskarna att detta är deras syn på det övernaturliga. Uppgiften kan jämföras med att 15,7 procent tror på en Gud som man kan ha en personlig relation till. Gruppen som inte tror har

5 Frågan är inte ställd i undersökningen från år 2006. 
minskat något sedan 1990 och utgör år 1999 13,3 procent. Undersökningen visar dock att andelen ateister ökat mellan 1982 och 1990. Skillnaderna mellan åren är signifikanta. Betraktas svarsalternativet 'en makt/ $\mathrm{kraft}^{\prime}$ som en indikator på andlighet borde den andliga revolutionens andlighet vara relativt utbredd i Sverige.

\begin{tabular}{|c|c|c|c|}
\hline \multicolumn{4}{|l|}{$\begin{array}{l}\text { Tabell 1. Inställning til en Gu } \\
\text { tive en makt eller kraft, Sveri } \\
\text { Källa: World Value Survey }\end{array}$} \\
\hline & 1982 & 1990 & 1999 \\
\hline & $(\%)$ & $(\%)$ & $(\%)$ \\
\hline Personlig Gud & 18,9 & 14,8 & 15,7 \\
\hline Makt eller livskraft & 38,9 & 43,8 & 52,4 \\
\hline Vet inte vad tro & 19,5 & 17,3 & 15,9 \\
\hline Tror into på någon Gud, makt eller kraft & 17,2 & 19,3 & 13,3 \\
\hline Vet inte & 5,6 & 0 & 0 \\
\hline Inget svar & 0 & 4,8 & 2,7 \\
\hline Total & $100 \%$ & $100 \%$ & $100 \%$ \\
\hline \multirow[t]{2}{*}{$\mathrm{N}$} & $\mathrm{n}=954$ & $\mathrm{n}=1047$ & $\mathrm{n}=1015$ \\
\hline & & & $\mathrm{p}<0,05$ \\
\hline
\end{tabular}

De svenska resultaten från WVS är tankeväckande samtidigt som de inte alls tar hänsyn till de problem som Fogelklou-Nordlind pekat på. När svarsalternativet 'Gud inom varje människa' introduceras i och med projektet Religious and Moral Pluralism (RAMP) förändras också svarsfördelningen radikalt vilket kan vara ett tecken på att alternativet 'makt eller livskraft' rymmer flera svar i ett alternativ. Andelen svenskar som instämde med 'Gud inom människan' (år 1997-1998) var 36,0 procent medan 19,7 procent valde alternativet 'en makt/kraft' (Gustafsson och Pettersson 2001).

Eileen Barker introducerade alternativet 'Gud inom varje människa' i RAMP med motiveringen att det är mindre personligt än 'en personlig Gud' men ändå inte så opersonligt 'som en makt/kraft' (Heelas \& Houtman 2009). Barkers forskningsbakgrund med fokus på nya religioner och New Age (den mest tongivande publikationen är The Making of a Moonie: Choice or Brainwashing? [1984]) har bidragit till att alternativet 'Gud inom människan' antagits vara ett komplement till en tro på en 'opersonlig makt $/ \mathrm{kraft}^{\prime}$ (se Heelas \& Woodhead 2005, 73-4) eller ett nytt sätt att mäta den andliga revolutionens andlighet (Heelas 2008; Heelas \& Houtman 2009). Lars Ahlin utgår också från att alternativet 'Gud inom människan' skulle vara en indikator på en icke-traditionell religiositet (Ahlin 2005, 52). Förutom Ahlin har åtminstone fem större svenska undersök- 
ningar (mellan 800 och 10.000 utskickade enkäter) använt alternativet 'Gud inom människan' sedan introduktionen. ${ }^{6}$

\section{Metod}

Resultaten som presenteras i denna artikel analyser baserade på två enkätundersökningar vilka båda samlades in inom ramen för Enköpingsprojektet. ${ }^{7}$ Båda enkäterna var relativt breda ämnesmässigt och berörde ämnen såsom religion, andlighet, hälsa och fritid. Enkäterna utformades med viss utgångspunkt i Kendalstudien och sökte aktivt besvara frågor om religion och dess förhållande till andlighet. Eftersom enkäterna endast är besvarade av människor i en kommun betraktas resultaten som giltiga för denna kommun. Det bör påpekas att hela undersökningen genomfördes år 2004-2005. Undersökningen ger alltså inte möjligheten att dra slutsatser om utveckling över längre tid.

I den kronologiskt sätt första enkätundersökningen (genomförd 2004) deltog ett obundet slumpmässigt urval av befolkningen i kommunen Enköping. Sammanlagt besvarades enkäten av 1045 personer vilket var 53,4 procent av dem som tillfrågades att vara med. Svarsbortfallet visar att fler gamla än unga valt att svara på enkäten samt fler kvinnor än män. Samtidigt råder nästintill perfekt matchning i fråga om partisympatier mellan dem som svarat på enkäten och senaste riksdagsvalet. Bromander tolkar det senare resultatet som att de som svarat på enkäten troligtvis hyser en motsvarande åsiktsbredd som finns i kommunen urvalet är gjort i (Bromander 2008).

Den andra enkäten riktades till producenter av alternativa hälsofrämjande tjänster i kommunen. Alternativmedicin definierades i studien som de hälsoföretagare vilka är registrerade under alternativmedicin i Statistiska centralbyråns företagsregister. Det betyder att verksamheten inte leds av en skolmedicinskt skolad läkare. Alternativmedicin innefattar på detta sätt ett relativt brett spektrum av verksamheter varav några uppfattas som alternativa i vardagligt tal (som exempelvis zonterapi) medan andra uppfattas som konventionella såsom reguljära gym och träningscentra. Definitionen motiverades av att många alternativa terapier (såsom kurser i yoga) numer även ges på reguljära gym. Företagsregistret kompletterades därefter med ledare från studiecirklar. Sammanlagt fanns 93 företag och permanenta studiecirklar i kommunen år 2005 av vilka 52 stycken (56 procent) svarade på den utsända enkäten. Bland de 56

6 Frågan används, med reservation för små avvikelser, i följande undersökningar: Ahlin 2005; 2007, Bromander 2004; Dahlgren 2008; Gustafsson \& Pettersson 2000; Larsson \& Willander 2007; Lövheim \& Sjöborg 2006.

7 Mot bakgrund av detta hänvisas, för en mer detaljerad bortfallsanalys och beskrivning av metoderna, till introduktionskapitlet “Guds närmaste Stad?" (af Ahlstrand, Palmer \& Willander) från Ahlstrand \& Gunner, eds., 2008; kapitlet “Enköpingsstudien: En religionssociologisk analys (Bromander 2008) samt kapitlet "Avslappnad och berörd. Synen på hälsa och andlighet bland hälsofrämjande företag i Enköping" (Willander 2008). 
procent som svarat är ungefär en lika stor andel som i branschen som helhet kvinnor respektive män. Även vad gäller inriktning på verksamheten verkar svarsfrekvenserna vara representativa. För en mer detaljerad beskrivning av studiens upplägg se Willander (2008).

Båda enkätundersökningarna följdes upp av semistrukturerade intervjuer. Urvalet av informanter från den första enkätundersökningen gjordes utifrån intentionen att fånga upp en åsiktsbredd i fråga om religion och andlighet. Mot bakgrund av den andra enkätundersökningens begränsade omfattning intervjuades alla deltagare som gav sitt medgivande till detta.

\section{Alternativmedicinens andlighet}

Resultatet från enkätundersökningen riktad till den alternativa hälsobranschen visar att 22 procent av hälsoföretagarna är kristna och lika stor andel är ateister och bör följaktligen inte betraktas som andliga i den andliga revolutionens bemärkelse. Av alla hälsoföretagare kallar sig ungefär 31 procent sig andliga. Här bör det tas i beaktande att alternativmedicin definierades så pass brett att gym och andra konventionella verksamheter inkluderades. Möjligen kan det också vara så att resultatet beror på att andlig inte uppfattas som en identitet (något som man är) utan något som man är med om. Denna tanke härstammar från intervjumaterial från Enköpingsstudien där intervjupersonerna själva väljer att prata om deras egna erfarenheter och upplevelser när de talar om andlighet (Palmer 2008). Vidare tillfrågades också hälsoföretagarna om deras verksamhet är andlig vilket närmare 70 procent ansåg att den var. Resultat är jämförbart resultat med Ahlins studie från Århus. Ahlin visar att 86 procent av de alternativa terapeuterna anser att andlighet är av betydelse för deras verksamhet (Ahlin 2007). Den vanligaste uppfattningen bland företagarna i Enköping var att verksamheten var andlig i någon mån och av alla företagare ansåg 17 procent att deras verksamhet var andlig i mycket eller ganska hög utsträckning. Utifrån enkätunderlaget delades också olika former av hälsofrämjande metoder delades in efter hur de utfördes. Indelningen åskådliggjorde att alla producenter som lade stor vikt vid att deras verksamhet var andlig arbetade med fysisk beröring (Willander 2008).

I intervjuer med de svenska företagarna framkom att andlighet främst är något som upplevs i stunder av återhämtning. Placeringen ger andligheten en framträdande position eftersom återhämtning och olika sätt att stressa ner bedöms vara mycket viktiga inom alternativt hälsofrämjande arbete. Karaktäristika likt dessa för tankarna till en andlighet med tydlig relation till hälsofrämjande. I ett försök att testa hypotesen om den andliga revolutionen genom en enkät till ett allmänt befolkningsurval kom Glendinning \& Bruce (2006) fram till att den alternativa andligheten troligtvis bör delas in i två delar. En första som rör hälsofrämjande och en andra vars fokus är horoskop och spådomsförutsägelser. Vidare fann Glendinning \& Bruce att där fanns 
överlapp av personer som både tog del av en kristen verksamhet på regelbunden basis och hälsofrämjande 'alternativ' andlighet (Glendinning \& Bruce 2006).

I enkäten som gick ut till allmänheten i Enköping ställdes en fråga om deltagande i alternativmedicinska terapier/metoder. Svarspersonerna tillfrågades om de utövat/ använt regelbundet eller prövat någon gång något av följande ${ }^{8}$ : meditation, örtmedicin/ homeopati, healing (reiki etc.), trumresor/schamanism, kristallterapi, rebirthing, astrologi/horoskop, frigörande dans/andning, tarot/spådomar, kontakt med medier/kanalisering, telepati, yoga, qi gong, tai chi, mirakelkursen samt ayur veda. Sammanlagt 436 personer (41,7 procent) använder/utövar alternativmedicin varav 83 personer använder/utövar regelbundet. 83 personer utgör 7,9 procent av hela befolkningsurvalet. Av de 83 personer som använder/utövar alternativmedicin regelbundet ägnar 24 personer även åt andligt utveckling. Möjligen kan dessa 24 personer betraktas som Enköpings motsvarighet till Kendalstudiens 'innersta krets' av andlighet. Dessa 24 personer utgör 2,3 procent av befolkningsurvalet vilket är nästintill dubbel så stor andel än den som Heelas \& Woodhead fann i Kendal.

\begin{tabular}{|c|c|c|c|}
\hline & Kristen & $\begin{array}{l}\text { Varken kri- } \\
\text { sten eller } \\
\text { inte kristen }\end{array}$ & $\begin{array}{c}\text { Inte } \\
\text { kristen }\end{array}$ \\
\hline Deltar i alternativmedicin & 48,7 & 45,5 & 40,0 \\
\hline Deltar inte i alternativmedicin & 51,3 & 54,5 & 60,0 \\
\hline Totalt & 100 & 100 & 100 \\
\hline \multirow[t]{2}{*}{$\mathrm{N}$} & $\mathrm{n}=273$ & $\mathrm{n}=303$ & $\mathrm{n}=395$ \\
\hline & & & ns \\
\hline
\end{tabular}

I detta sammanhang bör det understrykas (se tabell) att när de som utövar alternativmedicin ställs i relation till de som betraktar sig själva som kristna framkommer inga statistiska skillnader. Materialet visar istället att det är lika vanligt att vara kristen och utöva alternativmedicin som att inte vara kristen. Därför kan det inte uteslutas att den andliga utveckling som åsyftas bland de som deltar i alternativmedicin lika gärna vara

8 Frågan var utformad på följande sätt. Har du hört talas om eller prövat följande? Svarsalternativen var: 1) Utövar/använder regelbundet, 2) Har utövat/använt men slutat, 3) Har prövat någon gång, 4) Har bara hört talas om det, 5) Har inte hört talas om det. Mot bakgrund i att Heelas \& Woodhead (2005) definitierar 'de innersta kretsarna' av andlighet till dem som deltar i verksamheten har Enköpingsstudiens fråga kodats om till dem som deltar och dem som inte deltar. Bland de som inte deltar finns med andra ord både dem som känner till verksamheten och de som inte känner till verksamheten. 
kristen andlighet som 'alternativmedicinsk'. Resultatet skiljer sig från Heelas \& Woodheads studie vilka fann att religion och andlighet var 'olika världar'.

\section{Källan till det gudomliga som indikator för religion respektive andlighet}

Resultatet från enkätundersökningen riktad till befolkningen i Enköping visar att 24,4 procent tror att 'Gud snarare finns inom människan än utanför'. Vidare tror 16,4 procent på 'en makt/kraft'. Tillsammans gör detta att 40,8 procent av befolkningen kan sägas ha de trosföreställningar som Heelas \& Woodhead menar är andliga. Är detta då mycket eller litet? Först kan konstateras att det svarsalternativ som är vanligast är 'vet inte vad tro'. När svarsfrekvenser visar hög andel 'vet inte' svar brukar detta tolkas som ett tecken på att svarspersonerna upplevde frågan som svårbesvarad. Upp-gifterna från Enköping kan jämföras med resultaten från RAMP (genomförd 1997-1998) där exakt samma frågeställning användes. Jämförelsen visar att sammanlagt 55,7 procent uppgav en andlig tro 1997-1998 (36,0 procent trodde på ‘Gud inom människan' och 19,7 procent på en 'makt/kraft") vilket är en betydligt större andel än i Enköpingsstudien år 2004. Skillnaderna är signifikanta men kan bero på att den första studiens urval var hela Sverige medan den andra var kommunen Enköping.

\begin{tabular}{|c|c|c|}
\hline $\begin{array}{l}\text { Undersøkning } \\
\text { År }\end{array}$ & $\begin{array}{c}\text { RAMP } \\
1997-1998\end{array}$ & $\begin{array}{c}\text { Enköping } \\
2004\end{array}$ \\
\hline Personlig Gud & 18,0 & 14,6 \\
\hline Makt eller kraft & 19,7 & 16,4 \\
\hline Gud inom varje människa & 36,0 & 24,4 \\
\hline Tror into & 11,6 & 15,3 \\
\hline Vet ej vad tro & 14,7 & 29,2 \\
\hline Total & 100 & 100 \\
\hline \multirow[t]{2}{*}{$\mathrm{n}$} & $\mathrm{N}=1007$ & $\mathrm{n}=958$ \\
\hline & & $p<0,05$ \\
\hline
\end{tabular}

Inledningsvis fördes en kritisk diskussion de svarsalternativen om synen på källan till det heliga mäter skillnaden mellan religion och andlighet. Om alternativet 'Gud inom människan' speglar en skillnad mellan, å ena sidan, kristenhet och, å andra sidan, den andliga revolutionens andlighet borde där finnas skillnader mellan de som kallar sig själva kristna och dem som är aktiva inom alternativmedicin. En fördjupad analys av 
Enköpingsstudien visar att det troligtvis inte finns sådana skillnader. ${ }^{9}$ Istället tror genomgående cirka 30 procent på en 'Gud inom människan' inom grupperna (1) kristna, (2) aktiva utövare av komplementär eller alternativ medicin samt (3) producenter inom hälsobranschen. Resultatet är delvis förväntat då det tidigare visat sig att det bland de kristna finns aktiva utövare av alternativmedicin och vice versa. Det kan ändå understrykas att svarsalternativet 'Gud inom varje människa' är det vanligaste svaret bland producenterna av alternativmedicin tätt följt av svaret 'en högre makt eller kraft'. Vanligaste svaret bland de kristna var istället 'personlig Gud' (nästan 38 procent) vilket kan jämföras med 10 procent av dem som är aktiva utövare av alternativmedicin. Bland utövare av alternativmedicin var svaret 'högre makt eller kraft' det vanligaste. Sammantaget tyder resultatet på att begreppet 'personlig Gud' kan associeras med kristna och möjligtvis är svaret 'makt eller kraft' mer kopplat till alternativmedicin än begreppet 'Gud inom varje människa' vilket lika vanligt bland kristna som utövare och producenter av alternativmedicin.

Tabell 4. Syn på det gudomliga, procent. Källa: Enköpingsstudien 2004 och 2005

\begin{tabular}{|c|c|c|c|c|c|}
\hline & Kristna* & Religiösa* & Andliga* & $\begin{array}{l}\text { Aktive } \\
\text { utövare av } \\
\text { alternativ- } \\
\text { medicin }^{* *}\end{array}$ & $\begin{array}{l}\text { Producen- } \\
\text { ter av alter- } \\
\text { nativmedi- } \\
\quad \operatorname{cin}^{* * *}\end{array}$ \\
\hline Personlig Gud & 37,7 & 57,4 & 48,7 & 10,3 & 16,7 \\
\hline Högra makt eller & & & & & \\
\hline kraft & 17,9 & 18,5 & 25,6 & 35,9 & 27,1 \\
\hline Gud inom varje & & & & & \\
\hline människa & 30 & 20,4 & 21,8 & 29,5 & 29,2 \\
\hline Tror into & 1,6 & 1,9 & 1,3 & 10,3 & 12,5 \\
\hline $\begin{array}{l}\text { Vet inte vad ska tro } \\
\text { på }\end{array}$ & 12,8 & 1,9 & 2,6 & 14,6 & 4,6 \\
\hline Total & 100 & 100 & 100 & 100 & 100 \\
\hline $\mathrm{N}$ & $\mathrm{n}=257$ & $\mathrm{n}=54$ & $\mathrm{n}=78$ & $\mathrm{n}=83$ & $\mathrm{n}=48$ \\
\hline \multicolumn{6}{|c|}{$\begin{array}{l}\text { *= Som kristna, religiösa och andliga räknas de som valt att benämne sig själva som "helt } \\
\text { och hållet" eller "ganska mycket" i enkäten skickad till allmänheten inom ramen för En- } \\
\text { köpingsprojektet. } \\
* *=\text { Aktiva utövare av alternativmedicin har i enkäten skickad till allmänheten i kommunen } \\
\text { uppgette att de utövar/använder alternativmedicinska terapier eller metoder } \\
* * *=\text { Producenter av alternativmedicin utgörs har besvarat en separat enkät, endast skickad } \\
\text { til producenter af alternativmedicin }\end{array}$} \\
\hline
\end{tabular}

9 Eftersom de som själva kallar sig kristna också kan utöva alternativmedicin eller vara producenter kan tyvärr inte skillnaderna mellan dessa uppgifter testas med hjälp av till exempel chi två. 
Vad gäller självbenämningarna religiös och andlig verkar de inte heller ligga i linje med definitionerna stipulerade för den andliga revolutionen. Förvisso är instämmande med svarsalternativet "Jag tror på en Gud som man kan ha en personlig relation till" vanligast bland dem som benämner sig själva religiösa då 57 procent av dessa valt detta alternativ. Att tro på en personlig Gud är dock också den vanligaste inställningen bland de andliga och nästan hälften (49 procent) tror på detta sätt. Detta är också ett tecken på att de som betraktar sig som religiösa också betraktar sig som andliga vilket gör att samma personer ingår i gruppen 'andlig' och gruppen 'religiös'. Ur teoretisk synpunkt är dessa resultat delvis motsägelsefulla vilket kan bero på att självbenämningen 'andlig' är komplex. Andlighet är möjligen främst något individen är med om eller gör (Svalfors 2009; Palmer 2008). Därutöver, såsom redan nämnts, är det problematiskt att tala om alternativmedicin såsom en andlig inriktning.

Enkätfrågan om Gud verkar inte fungera som indikator på religion respektive andlighet såsom dessa begrepp är definierade för hypotesen om den andliga revolutionen. Statistiska signifikanta skillnader framkommer dock när kristna jämförs med icke-kristna och andliga med icke-andliga. Förväntade frekvenser åskådliggör att kristna och andliga tror i högre utsträckning än icke-kristna och icke-andliga. Frågor om Gud kan således betraktas som en indikator på religion till skillnad från frånvaron av religion och inte som en indikator vilken skiljer olika religiösa inriktningar åt. Mellan aktiva utövare av alternativmedicin och ej aktiva finns inte motsvarande skillnader i frågan om synen på Gud. Deltagande i alternativmedicin verkar således inte påverka synen på Gud.

En möjlig tolkning av detta är att skillnaden mellan religion och andlighet tydligare kommer till uttryck genom andra dimensioner av religion/andlighet. En sådan tolkning skulle kunna bereda väg för kritik av det centrala antagandet att det gudomligas placering är av avgörande betydelse för den religion som konkurrerar med andlighet i den andliga revolutionen. Ytterligare en tolkning är att svarsalternativen om Gud inte mäter det som de antagits mäta (det vill säga synen på källan till det gudomliga eller det gudomligas rumsliga placering).

\section{Diskussion}

Hypotesen om den andliga revolutionen har fått stor genomslagskraft i religionssociologisk forskning. En förklaring till detta är den koppling som Heelas \& Woodhead (2005) gör till tidsandan i västerländsk kultur. Utifrån Taylor (1989) menar Woodhead \& Heelas att västvärlden genomgår "a massive subjective turn" vilken för med sig ett skifte från en kultur vilken premierar kollektivism till en kultur där individualism och till och med subjektivism uppmuntras. Taylor har efter Heelas \& Woodheads formulerande av den andliga revolutionen utkommit med ytterligare ett arbete kallat $A$ Secular Age (Taylor 2007). Här argumenterar Taylor för att vår samtida västvärld hyser särskilda förutsättningar för tro vilka bland annat kännetecknas av den utbredda 
kunskapen om att ens egna trosföreställningar inte behöver delas av andra. Taylor skriver:

The shift to secularity [...] consist of a move from a society where belief in God is unchallenged and indeed, unproblematic, to one in which it is understood to be one option among others, and frequently not the not the easiest to embrace (Taylor 2007, 3).

Skiftet berör hela samhället vilket troligtvis påverkar all religion (kristendom och new age). Heelas \& Woodheads tolkning av "the massive subjective turn" är att andlighet vilken ligger i linje med kulturen kommer att växa på bekostnad av religion vilken utgör en motvikt till kulturen. Tolkningen tar inte hänsyn till att det som betraktas som religion och andlighet ständigt förändras. En annan tolkning är att de värden som vår samtid värderar påverkar all religion men att värdena kommer tydligast till uttryck i andlighet vilken kan kopplas till new age eftersom denna andlighet stod för dessa värden från början. Tolkningen innebär ett perspektivbyte från särskiljandet och storleksbestämmandet av olika religiösa eller andliga inriktningar i vår samtid till studier av samspelet mellan samtida kultur och religiösa och andliga uttryck i stort.

Den empiriska analysen i denna artikel understryker att religion och andlighet svårligen kan definieras som kristendom respektive alternativmedicin. Kristendom och alternativmedicin verkar inte stå i konkurrensförhållande till varandra varpå deltagare i alternativmedicin kan betrakta sig själva som kristna. Trosföreställningar om källan det gudomliga (utanför eller inom människan) mäts troligtvis inte med nuvarande frågeställningar om synen på Gud. För kommande studier behövs därför frågeställningarna preciseras. Detta arbete bör inkludera att frågan om en individ tror särskiljs från vad samme individ tror på.

Hypotesen om den andliga revolutionen hyser en stor styrka i kopplingen mellan vår tids kultur och dess påverkan på religion och andlighet. Härutöver kan särskiljandet mellan en yttre och en inre helig referens komma att vara användbar för att förstå religion och andlighet $\mathrm{i}$ vår samtid. Begreppsförståelsen av religion och andlighet såsom kristendom och alternativmedicin behöver dock omarbetas. Omarbetningen kan med fördel ta sin utgångspunkt $\mathrm{i}$ hur begreppen religion och andlighet används i vardagligt språkbruk.

\section{REFERENSER}

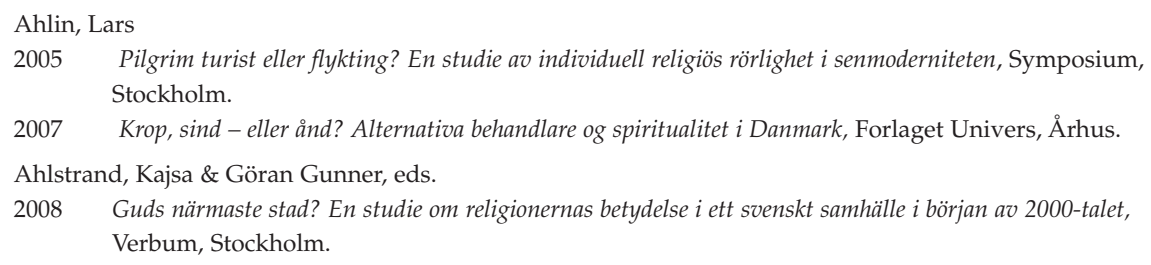


Barker, Eileen

1984 The Making of a Moonie: Choice or Brainwashing? Blackwell Publishers, Oxford.

2004 "The Church Without and the God within: Religiosity and/or Spirituality?" in: Dinka Marinovic, Sinisa Zrinscak \& Irena Borowik, eds., Religion and Patterns of Social Transformation, Institute for Social Research, Zagreb.

Bromander, Jonas

2004 Medlem i Svenska kyrkan: En studie kring samtid och framtid, Verbum, Stockholm.

2008 "Enköpingsstudien: En religionssociologisk analys", in: Kajsa Ahlstrand \& Göran Gunner, eds., Guds närmaste stad? En studie om religionernas betydelse i ett svenskt samhälle i början av 2000-talet, Verbum, Stockholm

Dahlgren, Curt

2008 Att lämna sitt trossamfund. Några sociologiska perspektiv, Arcus förlag, Lund.

Fougelklou-Nordlind, Emilia

1934 Vad man tror och tänker inom svenska folkrörelser, Gunnar Saietz förlag, Stockholm.

Glendinning, Tony \& Steve Bruce

2006 "New ways of believing or belonging: is religion giving way to spirituality?", The British Journal of Sociology, 57 (3), 399-414

Gustafsson, Göran

1981 Religionen i Sverige. Ett sociologiskt perspektiv, Scandinavian University books, Stockholm.

Gustafsson, Göran \& Thorleif Pettersson, eds.

2000 Folkkyrkor och religiös pluralism - den nordiska religiösa modellen, Verbum, Stockholm.

Heelas, Paul

2008 Spiritualities of Life. New Age Romanticism and Consumptive Capitalism, Blackwell Publishing, Oxford.

Heelas, Paul \& Dick Houtman

2009 "Research Note: RAMP Findings and Making Sense of the 'God Within each Person, Rather than Out There'" Journal of Contemporary Religion 24 (1), 83-98.

Heelas, Paul \& Linda Woodhead, eds.

2005 The Spiritual Revolution. Why Religion is giving way to Spirituality, Blackwell Publishing, Oxford.

Hössjer Sundman, Boel

2006 "Herren är mitt ibland oss": en analys av Gudsnärvaron i Den svenska kyrkohandboken från 1986, Artos, Skellefteå.

Larsson, Anna \& Erika Willander

2007 Vägen till nöjda konfirmander. Rapport över samtliga svar i projektet Konfirmand 2006 (reviderad digital utgåva), Svenska kyrkan, avdelningen för utbildning, forskning och kultur, Uppsala.

Löwendahl, Lena

2002 Med kroppen som instrument: en studie av new Age med fokus på hälsa, kroppslighet och genus, Almqvist och Wiksell, Lund.

Lövheim, Mia \& Anders Sjöborg

2006 Varför Kyrkan? Ungas röster i Stockholms stift, Diakonivetenskapliga institutets skriftserie 14, Uppsala.

Newport, Frank

2008 Belief in God far Lower in Western U.S.. Overall, 78 \% believe in God, 15 in a higher spirit, Gallup, Washington.

Palmer, Brian

2008 "Ryck ut jacken - Andlighet som en paus i livsstressen" in: Kajsa Ahlstrand \& Göran Gunner, eds., Guds närmaste stad? En studie om religionernas betydelse i ett svenskt samhälle i början av 2000-talet, Verbum, Stockholm

Rosengren, Anna \& Anna-Karin Nilsson

2007 Spa för själen, Verbum, Stockholm. 
Svalfors, Ulrika

2009 Andlighetens ordning. En diskursiv läsning av tidskriften Pilgrim, Acta Universitatis Upsaliensis, Uppsala.

Taylor, Charles

1989 Sources of the Self: The Making of the Modern Identity, Cambridge University Press, Cambridge.

2007 A Secular Age, Harvard University Press, Cambridge.

Voas, David \& Steve Bruce

2007 "The Spiritual Revolution: Another False Dawn for the Sacred", in: Kieran Flanagan \& Peter C. Jupp, eds., A sociology of spirituality, Ashgate, Alderstone.

Willander, Erika

2008 "Avslappnad och berörd. Synen på hälsa och andlighet bland hälsofrämjande företag i Enköping" in: Kajsa Ahlstrand \& Göran Gunner, eds., Gus närmaste stad? En studie om religionernas betydelse i ett svenskt samhälle i början av 2000-talet, Verbum, Stockholm.

\section{HEMSIDOR}

http:/ /www.worldvaluessurvey.org/ (set 29.05.09) (red.)

http://www.lancs.ac.uk/fss/projects/ieppp/kendal/ (set 29.05.09) (red.)

Erika Willander, doktorand Sociologiska institutionen, Uppsala Universitet 